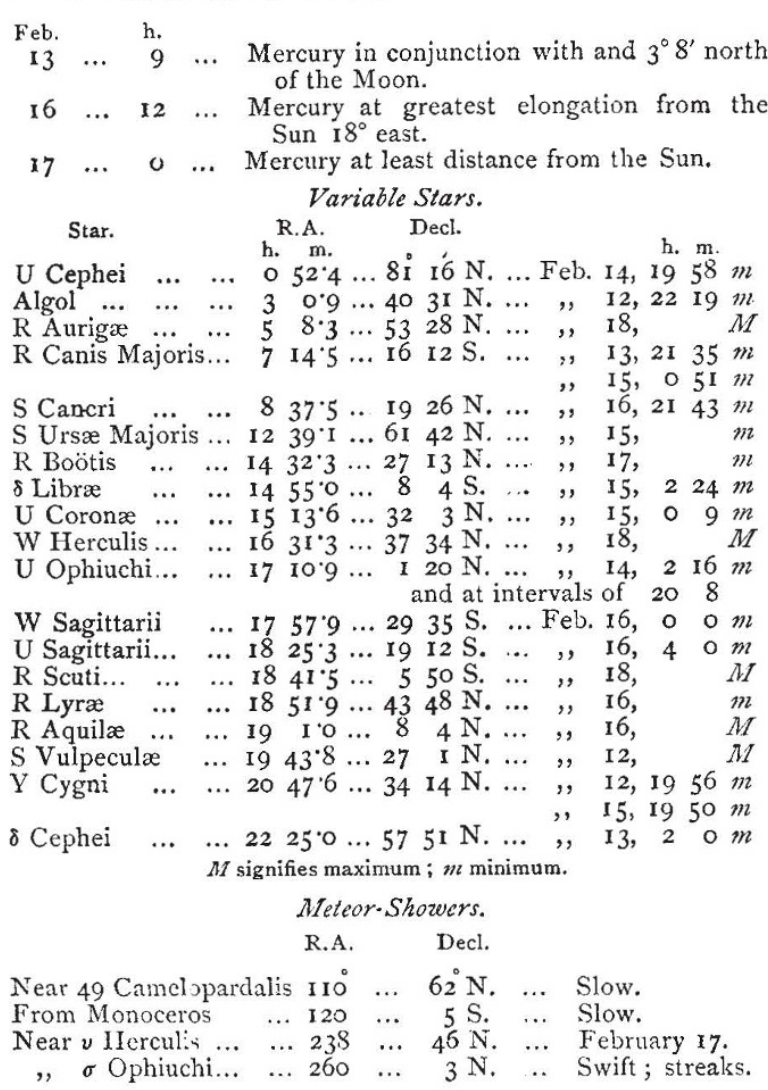

\section{GEOGKAPHICAL NOTES}

THE French traveller, $M$. Th suar, who was believed to have perished on his way to the Gran Chaco, has returned to Port Pacheco with his companions. This news was lately sent from Buenos Ayres to Chuquisaca (Sucré).

In the new number of Appalachia Mr. F. H. Chapin describe his ascent of a glacier on Mummy Mountain, Northern Colorado, lying directly north of Long's Peak, and in line with the centre of Estes Park. A single glance at the series of crevasses convinced $\mathrm{Mr}$. Chapin that it was really a glacier, and not a mere accumulation of snow. To the same number Mr. S. HI. Scudder contributes a paper on the White Mountains as a home for butterflies.

In the paper contributed to the Berlin Geographical Society by Dr. H. Meyer on his ascent of Mount Kilimanjaru, he modifies his first statements as to the height which he attained according to a statement of his companion, Dr. Meyer did not get within 2000 feet of the top.

In the new Bulletin of the A nerican Geographical Society will be found a useful paper by Mr. A. S. Packard, in which he brings together a précis of what was known of Labrador. Accompanying the paper is a good map, in which Mr. Packard has embodied information hitherto unpublished. Dr. Fr. Boas gives the results of his year's sojourn among the Eskimo.

In the last number of the Proceedings of the Victoria Branch of the Australasian Geographical Society will be found a detailed account of Mr. Cuthbertson's expedition to explore the highlands of British New Guinea. The accompanying map gives a good idea of the nature of the country. Mount Obree was found to be only 8000 feet high, 2000 feet lower than previous estimates.

We learn from the Izuestia of the East Siberian Branch of the Russian Geographical Society (vol. xvii. fasc. I) that the vertical section of the Angara at its issue from Lake Baikal is 17,920 feet, and that the volume of water discharged from the great Sibeiian lake reaches $12 \mathrm{I}, 353$ cubic feet per second, If this outflow were checked, the level of the lake would rise 7 feet in thirteen months.

Dr. Robert Siegre contributes to the Geographical Society of Vienna University a paper in which he discusse; what in formation exists as to the changes of level in the African lakes. This shows clearly that for the last ten years at least these have been lowering in level, and, in the case of Tanganyika, to the extent of many feet. The changes which take place are almost entirely dependent on rainfall, and the probability is that there are periods of depression and periods of elevation. It is important that observations should be carried on both in African lakes and African rivers for a period sufficiently long to afford data numerous enough to warrant any conclusion to be drawn.

Prof. FuARD Süss, the able author of "Das Antlitz der Erde," recently read a paper to the Vienna Geological Society, on the history of the ocean, which is to some extent supplementary to that work. In this he point; out that from the mouths of the Ganges all round the Pacific crasts of Asia and America to Cape Horn, the coasts are outlined by mountain-ranges which close in upon each other in great curves. From Cape Horn, again, all round the Atlantic and the Indian Oceans to the mouths of the Ganges, the coasts are unconnected with mountainranges, but are encircled by table-lands or broken mountain patches. We have thus, then, so far as the structure of the ocean basins is concerned, to distinguish between a Pacific and an Atlantic type. As regards the age of the oceans, Prof. Siiss conciudes from the geo'ogical formations that the Pacific is the oldest, next to that the Indian, and last of all the Atlantic. The oceans, he points out, are areas of depression. Each new depression would form a fresh receptacle for water, and so the shore-line of the land would be lowered. Prof. Siiss seems to maintain that it is to this, and not to the actual rising of the land, that the elevation of the coast-line in certain regions is due.

Mr. J. F. Needham has been engaged to conduct an expedition from Sadiya to the Hukeng Valley, and thence to Bhamo on the Upper Irra wady. His previous achievements in the Abor IIills, and the country lying between the Brahmaputra and the Zayal Chu, and his success in conciliating the unfriendly tribes on that frontier region, marked him out for selection as the proper officer to conduct the present mission.

THE new part (Nos. 133-34) of the Zeitschrift of the Berlin Geographical Society is mainly occupied with Dr. W. Sievers's account of the results of his exploration of the Sierra Nevada of Santa Marta in the north-east of the United States of Columbia, an excellent large-scale map accompanying the number. A considerable section of the paper deals with the geology of the region, after which Dr. Sievers treats of the surfice formation, altitudes, climate, vegetation, and agriculture, the land-snails population.

News from Victoria, in the Cameroons, states that the African traveller, Dr. Zintgraff, started for Rio del Rey in the steamer Nachtigal, accompanied by thirty porters. He is on his way to the Elephant Lake in order to esta'blish a scientific station. The other half of the Expedition, under the command of Lieut. Zeuner, is to pruceed up the Mungo River to Mundame, to reach the Elephant Lake from that part.

\section{OUR ELECTRICAL COLUMN.}

If a platinum plate be immersed in a porcelain or glass vessel containing dilute sulphuric acid, and another similar plate be immersed in another vessel containing caustic potash solution, then if the two vessels be connected by a siphon tube or a cotton wick, a current will be set up, but which rapidly diminishes oxing to the polarization of the metal plates by the deposition of oxygen and hydrugen upon them. Becquerel removed the hydrogen by using nitric instead of sulphuric acid, and increased the current considerably. Dr. Alder Wright and Mr. C. Thomson (Koyal Society, February 2, 1888) have been examining this form of battery, and have found many other acids which act in the same way, such as potassium permanganate, potassium bichromate, potassium ferricyanide, and bromine dissolved in sulphuric acid, ferric chl rride, hydrochloric acid and chlorine. Moreover, they have removed the oxygen by using a concentrated solution of sodium hyposulphite made strongly alkaline with caustic soda, strong caustic soda with pyrogallol, cuprous chloride, ferrous sulphate, and ammonium chloride dissolved in ammonia. They also found the quantity of oxygen 